\title{
Task and Relationship Orientation of Professionals in Afghanistan and Thailand
}

http://doi.org/10.21272/bel.5(2).6-20.2021

Bahaudin G. Mujtaba, ORCID: https://orcid.org/0000-0003-1615-3100

D.B.A., Professor, College of Business and Entrepreneurship, Nova Southeastern University, USA

Tipakorn Senathip, ORCID: https://orcid.org/0000-0002-0943-233

MBA, Institute of International Studies, Ramkhamhaeng University, Thailand

Jatuporn Sungkhawan, ORCID: https://orcid.org/0000-0003-0630-5182

D.I.B.A., Southeast Bangkok College, Thailand

\begin{abstract}
The purpose of this paper is to analyze the leadership styles and approaches that are linked to Afghan and Thai respondents by exploring their task and relationship orientations to glean best practices for application in the war-torn nation of Afghanistan. To continue gathering more data, we have consistently been using Northouse's Style Questionnaire to collect responses from different cultures over the past two decades. More specifically, for this latest study, we compared the leadership orientations of working adult respondents from Thailand and Afghanistan based on their nationality and socialization in each culture on the task and relationship-orientation continuum of leadership. To gain practical insights across these two Asian cultures, we reflect and explore the Afghan orientation and compare it with the cultural practices of people in Thailand, where politicians have managed their political affairs more peacefully with their neighbors. Both Afghanistan and Thailand's cultures are rooted in thousands of years of Asian philosophies, and both are high-context and collective; therefore, people are presumed to be more relationship-oriented, and this study found statistically significant support for this presumption. While respondents from both countries do have a stronger focus on their relationships, data shows that their task orientation is significantly lower. Analysis, recommendations for inclusion training, dealing with societal / workplace mobbing, and the study's limitations are presented toward the end of the paper. The findings are useful for training purposes with managers, political leaders, and expatriates working in these two South and East Asian countries. For example, currently the political leaders in Afghanistan are working with the international community to unite all Afghans so they can become less dependent on foreign forces to keep the country peaceful. As such, they can capitalize on their task and relationship orientation skills to work on this gigantic task. Similarly, as of May 2021, Thailand has been experiencing another wave of the Covid-19 coronavirus, with about 10,000 infection cases on some days; as such, Thai leaders have to build strong relationships with everyone in the country to effectively manage this task of limiting the spread of this deadly infection through strict quarantine rules and quick vaccination of their large population.
\end{abstract}

Keywords: Afghan Leadership Orientation, Thai Cultural Orientations, Relationship-Orientation, TaskOrientation, Inclusion, Training, Societal Mobbing.

JEL Classification: Z1, M53.

Cite as: Mujtaba, B.G., Senathip, T., Sungkhawan, J. (2021). Task and Relationship Orientation of Professionals in Afghanistan and Thailand. Business Ethics and Leadership, 5(2), 6-20. http://doi.org/10.21272/bel.5(2).6-20.2021.

Received: 07 May $2021 \quad$ Accepted: 02 June $2021 \quad$ Published: 25 June 2021

Copyright: (C) 2021 by the author. Licensee Sumy State University, Ukraine. This article is an open access article distributed under the terms and conditions of the Creative Commons Attribution (CC BY) license (https://creativecommons.org/licenses/by/4.0/).

\section{Introduction}

The leadership styles and practices of people worldwide, especially Asians, have been discussed for thousands of years through rituals and stories being passed on from one generation to the next (Mujtaba, 2019b). Modern researchers and academicians write about the specific leadership styles of managers from across the globe, and some focus on better understanding their task and relationship orientations. The focus of task and relationship orientations can be observed in how different countries have responded to the Covid-19 coronavirus pandemic as some countries have been more task-oriented to reduce the number of deaths (such as New Zealand, Canada, 
China, Singapore, South Korea, and Thailand). Others have suffered more due to cultural socialization of maintaining relationship rituals (such as Italy, Iran, Afghanistan, India, Brazil, and the United States) (Korman and Mujtaba, 2020). To explore the behavioral tendencies of working adults in the Afghan and Thai workplaces, we review the socialized norms of Afghan and Thai cultural practices while scientifically assessing their similarities and differences to gain insights for application in the modern workplace.

Afghans and Thais are likely to be relationship-oriented because their cultures are in Asia, collectivistic, and influenced by Buddhism (2019a). While Afghans are majority Muslim today and Thais are majority Buddhists, the people of both countries have a good understanding of different spiritual views due to their centuries of being influenced by Islamic and Buddhism practices. Similarly, the people of both cultures are family-oriented and somewhat paternalistic. Perhaps because of this relationship-oriented society, people in Thailand seem to be more tolerant, internationally diverse, and inclusive of the world's cultures, enabling their politicians and entrepreneurs to benefit from globalization trends and foreign direct investment opportunities. On the other side, despite their collective and relationship-oriented culture, the people of Afghanistan have had political upheavals, widespread corruption, and several regressive political regimes over the past four decades, which has hurt their economy (Mujtaba, 2013). Afghans can learn from the Thais best practices to improve their work environment and political economy since there are links and connections between cultural leadership practices and a nation's economic performance (Misumi and Seki, 1971; Misumi, 1986; Mujtaba, Tajaddini, and Chen, 2011; Hughes, Ginnett, and Curphy, 2019). As such, we review the literature on traditional leadership and the general management styles of managers in Afghanistan and Thailand, along with their cultural norms. Then, we explain our methodology, research hypotheses, and the results. Finally, we discuss general implications, limitations, training opportunities, and conclusions of the study.

Culture and Behavior. Modern workers living in a globalized work environment have been exposed to many diverse cultures as people travel abroad for global education or work (Karadjova-Stoev and Mujtaba, 2009) and through the use of modern technology. As such, there might be a convergence, divergence, and crossvergence of cultural practices and leadership styles present in their behaviors (Nieves, Mujtaba, Pellet, and Cavico, 2006). Convergence describes the merging of different cultures due to globalization and other factors that bring them into close contact with one another. Divergence is the extent to which a specific culture exhibits distinctiveness despite interaction with other cultures. Finally, crossvergence is the development of a new culture with its characteristics that result from cultures interacting with each other over time (Dastoor, Roofe, and Mujtaba, 2005). Most importantly, modern Afghans and Thais living in rapidly growing cities of Kabul and Bangkok tend to exhibit individualistic values associated with western economies. Westerners have adopted many high-context cultural practices since employers encourage employees to work collectively in achieving organizational goals and understand that in "highly competitive, rapidly changing environments, caring and appreciative leaders bet on for long-term success" (Kouzes \& Posner, 2003: 78). The call for participative management and continuous improvement practices through concurrent engineering and teamwork has been advocated in Western industries for many decades (Kreitner, 2007). In essence, the forces of globalization are inducing changes in all cultures (Adler, 1986), mainly democratic nations like Thailand, which has welcomed scholars, entrepreneurs, and investors from all over the globe.

Culture is a prominent factor in the differences people share. Such differences can be critical in effectively managing workplace diversity and inclusion, which is why so many researchers have studied such relationshipbuilding opportunities across the globe (Al-Kwifi, Khoa, Ongsakul, \& Ahmed, 2020; Ali, \& Al-Aali, 2016; Arslan \& Dikova, 2015; Lee and Suwimol, 2018; Ng \& Tung, 2018). Additionally, culture is essential because shared values tend to regularize human behavior and make individuals more predictable. Knowing how others perceive and value their environment provides a guide for managers to anticipate behavior and respond effectively. This point is becoming increasingly more important as globalization brings distant peoples into closer contact while they face cultural, economic, and legal challenges (Scarborough, 1998). The growth in international trade has dramatically increased people's understanding of the similarities and differences between diverse cultures (Gardenswartz, Rowe, Digh, \& Bennett, 2003).

Afghanistan is a country trying desperately to recover from decades of ethnic conflicts. The lack of progression in Afghanistan and the presence of widespread corruption are partly due to cultural disintegration. Sims and Mujtaba (2005) warn that corruption can significantly damage and slow the growth process of an economy. These are not the people of Afghanistan that are corrupt; instead, the realities of low-paying jobs and a terrible economy have conditioned some people to accept inappropriate actions such as drug trafficking, theft, and bribery as an essential element of day-to-day survival. Sims and Mujtaba's research conclude that ongoing corruptive practices within the public sector have enormous implications on the security of the Afghan government. Citizens unhappy with the unfair, inequitable, and untimely distribution of public services can 
resort to revolts and other negative behaviors; such behaviors play a significant part in the regression of a nation and its demographics. As such, an awareness of the people's leadership orientation toward tasks and relationships may help understand such long-lasting conflicts and corrupt practices in Afghanistan. Strong leaders should be "guided by a commitment to work for justice and equality, among those who are disenfranchised and underserved" (Lawrence-Lightfoot, 2000: 83).

The studies on cultural differences (Munene, Schwartz, and Smith, 2000) conclude that Asian cultures like Thailand and Afghanistan emphasize hierarchy, paternalism, and mastery in contrast to egalitarianism, autonomy, and harmony (Huang, Mujtaba, Cavico, and Sims, 2006). Moreover, Asian managers often stress reliance on formal rules and superiors in reaching decisions compared with the cultural profile of people in Canada, the United States, and most European countries. In today's competitive world, understanding and responding to culturally driven behaviors are paramount to succeeding (Habil, Aboramadan, and Zaqout, 2019), especially in cross-cultural management because "the people in an organization are crucial to its performance and the quality of work-life within it" (Rainey, 2003: 219). Afghanistan and Thailand are high-context cultures where people tend to socialize as part of their cultural mores. However, due to cultural convergences, more and more people are also demonstrating individualistic values as they attempt to secure long-term independence from undue foreign aid and political influences. Navigating between individualistic and collectivistic cultures and recognizing the shifts in diverse cultures can directly impact how international firms and their people perform. People of an individualistic culture tend to value the needs, concerns, and identity of oneself above the community's needs, which contribute to the traditional Asian norms. We know that a collective culture's citizens and inhabitants are generally socialized to focus more on world peace, being helpful to others and group interests instead of an individual's needs. This study seeks to expand our knowledge of Afghanistan's leadership culture by directly comparing Afghans and Thais' task and relationship orientation. While the scope of this study is limited, the goal is to expand our knowledge of leadership across cultures through the systematic collection of data and empirical analysis. This knowledge can then be used to improve the international community's understanding of these Asian cultures and facilitate their continued stability and economic prosperity in the coming years and decades (Oyserman, 2002; Schwartz, 1994, 1999).

Today's environment of global competition and fears of Covid-19 has changed many aspects of work in dramatic ways (Mujtaba, Cavico, and Senathip, 2020; Ibrahim, Imtiaz, Mujtaba, Vo, \& Ahmed, 2020; Ahmed, Khan, Khan, \& Mujtaba, 2020; Ahmad, Hussain, Saleem \& Qureshi, 2015). However, peoples’ thinking regarding violence, indulgence, and greed still tends to drive their behaviors about the accumulation of wealth through moral, immoral, and amoral means in society. It has been said that ineffective or insufficient management theories and concepts widespread both in the private and public sectors of Afghanistan and Thailand tend to lead to bad practices and often do more damage than what is apparent to the naked eye (Ghoshal, 2005). According to some experts, the twenty-first-century world has achieved modernity and brilliance without developing a higher level of conscience since this world has many "nuclear giants and ethical infants" (Drumm, 2002: 17). Reischl, Cavico, Mujtaba, and Pellet mention that "Although the natural sciences paved the way for advancement in the quantity of life, little has changed in the way of advancement in the quality of life" (2010: 7). Afghan officials should emphasize that effective leadership means doing the right tasks at the rights times while building long-term relationships with all relevant stakeholders in organizations, communities, region, and society (Mujtaba, 2007a).

Afghan and Thailand's Culture. Cultures are necessary as they help us to learn best practices and behave within certain norms that can keep us safe and functional in society. These cultural practices are traditionally passed on from one generation to the next in Asian cultures like Afghanistan and Thailand through their familial connections and storytelling. These cultural norms regularize behavior and make one's actions consistent and thereby predictable. Academically, we know that culture is "The collective programming of the mind that distinguishes one human group members from another. Culture, in this sense, includes systems of values; and values are among the building blocks of culture" (Hofstede, 1980: 21). The behavior of Thais and Afghans reflects their years of socialization and native roots based on their various beliefs, norms, and mores passed on from one generation to the next for thousands of years. We know that cultures regularize human behavior, thereby making decisions more predictable and most Asians find comfort in knowing how everyone is expected to behave. Culture plays an important role in acting as moral leaders and being perceived as ethical managers locally, nationally, and globally (Sanyal, 2005).

However, we also know that the Thai culture differs from the Afghan culture in some ways. Afghan managers often use more directive leadership styles, while Thais tend to be more democratic and participative in their management and decision-making approaches. While Afghanistan has a growing population of about 40 
million inhabitants as of 2021, Thailand's population is about 75 million. Furthermore, while there are millions of Muslims in Thailand, most people are Buddhists. In Afghanistan, 99\% of the population is Muslim today, but Buddhism used to be popular in Afghanistan over one thousand years ago prior to the introduction of Islam. Thais enjoy much more freedom and pragmatism, as people are economically in a better position, flexible and more open-minded toward new ideas compared to the average person in Afghanistan. As can be witnessed, Thais have adopted many western practices, perhaps due to the constant evolution of culture and widespread availability of technology and information. Similarly, in search of a better economy and a peaceful country, Afghans have adopted many diverse Western and Asian practices to encourage employees to work more collectively to achieve the organization's goals in a very competitive and globally open society. In essence, modern practices and focus on competitiveness and high expectations from the international communities have induced favorable changes in both Afghan and Thai cultures. In Thai culture, where collectivism is high and individualism is low (Figure 1), the group is the primary unit of the social organization due to people living in extended families, which explains why it is easier for them to work cohesively as teams and groups. Similarly, power distance and uncertainty avoidance are high, while achievement and long-term orientation are on the lower side as people have become more indulgence-oriented.

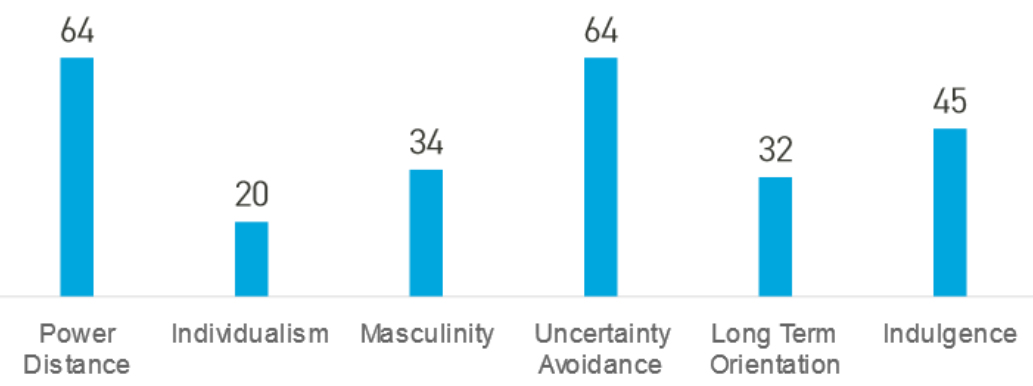

Figure 1. Thai Cultural Dimensions Scores

Source: https://www.hofstede-insights.com/

While there is no published empirical research data available based on Hofstede's cultural dimensions as of yet for the culture of Afghanistan, there are some practical explanations from researchers (Entezar, 2008). In general, based on two decades of socialization and personal observations of the first author along with the results of qualitative interviews with educators and leaders in Afghanistan, power distance between workers and managers is high for Afghans since formal position title and rank tend to have a high level of importance both on the job and in the community. Both masculinity and uncertainty avoidance are relatively high in Afghanistan as the concept of "guzaara" conditions people to "play it safe" and not take too much risk. Since Afghans do put their faith in God, some authors believe that many individuals have low uncertainty avoidance tendencies (Entezar, 2008). However, as a country, Afghanistan is a culture of cautious optimists and calculated risk-takers; consequently, most people avoid unnecessary uncertainty and risk. On the other side of the continuum, individualism and long-term orientation are in the medium range. Finally, Afghan's indulgence score is likely to be in the low range since people are conditioned by the local norms of uncertainty avoidance and other cultural traditions to avoid extravagant expenditures and save for a "rainy" day. Due to the collective nature of people in Afghanistan and the history of tribalism, most individuals learn to socialize and respect members of the community, especially their elders. While Afghans do restraint themselves from acting upon their impulsive indulgences, some of their decisions are short-term oriented as the years of political instability, widespread corruption, and ethnic conflicts have conditioned many toward a survival mode of making it through the day or even the current political regime.

Hall (1976) divides culture into two extreme types: high context and low context cultures. In high context cultures, people share their way of thinking, feeling, and acting; therefore, they often use non-verbal communication. On the contrary, in low-context cultures, people utilize verbal communication. Thailand, like Afghanistan, is a high-context society. It partly explains why the Thai and Afghan people tend to avoid uncertainty. Afghans and Thais try to build strong and stable relationships with others. Due to their highcontext and homogenous cultures, people can more effectively communicate with each other. Thais and Afghans have thousands of years of Asian culture and history, which still drives people's behavior in achieving their goals while maintaining strong work relationships. The cultures of these countries are somewhat 
paternalistic due to strong relationship orientations and the reciprocal expectations of loyalty and favoritism linked with it. Culture is important because shared values tend to regularize human behavior while making politicians and managers more predictable, which has important work implications (Schwartz, 1999). Knowing how others perceive and value their environment provides a guide for managers and politicians to anticipate behavior and respond effectively as leaders in their departments and societies (Gardenswartz, Rowe, Digh, \& Bennett, 2003; Cavico and Mujtaba, 2008).

Leadership is about effectively influencing to achieve organizational objectives (Habil, Aboramadan, and Zaqout, 2019). In the behavioral perspective of leadership, two clusters of behaviors focus on the people and tasks. First, people-oriented behaviors include showing mutual concern, trust, and respect for others. Peopleoriented leadership tends to result in higher job satisfaction among subordinates and lower absenteeism, grievances, and turnover compared to using a task-oriented style. However, Mujtaba (2019) mentions that job performance tends to be lower than for employees with task-oriented leaders. Second, task-oriented leadership styles generally include behaviors that define and structure work roles to ensure that everyone follows the established rules to reach performance capacity and meet the standards. An unintended consequence or side effect of task-oriented leadership is that it can result in lower job satisfaction and higher absenteeism and turnover among subordinates (Hersey, Blanchard, and Johnson, 2001). Behavioral leadership scholars conclude that most individuals are somewhere in between in the continuum (Hersey, 1984).

Buckner (Buckner, 2019: 315) mentions that "Higher education institutions (HEIs) are increasingly being called upon to educate youth for global labor markets and societies." Buckner states that many HEIs "have integrated international and intercultural ways of knowing into their work. This phenomenon is internationalization" (Buckner, 2019: 315). Afghanistan has a young population that should be trained, developed, and socialized toward critical thinking leadership skills and economic development through the global education of best practices from around the world. Baha (Baha, 2019: 5) believes that "it is predicted that the number of students will increase by approximately $12 \%$ annually for the next four years" in the higher education section of Afghanistan, which was initiated in the 1930s. The fact is that while about 50,000 students were annually entering higher education in 2008 , today, nearly 400,000 students are expected to be enrolled during 2020 in the higher education institutions of Afghanistan (Baha, 2019: 5). Research shows that university graduates now need various intercultural competencies to participate in the global labor markets (Buckner, 2019: 317). Consequently, the training and development of modern students, educators, political leaders, and entrepreneurs for effective leadership become important as future leaders begin their higher education journey.

Afghan leaders must keep in mind that certain aspects of the Afghan culture, such as strong bonds among friends and reciprocal expectations of loyalty, tend to lead to favoritism among all public and private sector professionals. This cultural foundation associated with loyalty to one's friends and colleagues or even cronyism in Afghanistan has evolved over the years out of socialization and necessity. One can trust his or her closest friends in times of turmoil and political conflicts. While some elements of favoritism and cronyism are prevalent in most cultures, including Thailand, it is especially true in Afghanistan since there is a diverse range of ethnic groups and tribes divided through political animosity by foreign influences in a land-locked country. As such, this study seeks to identify the extent to which the leadership orientations of Afghans are similar or different by examining their task and relationship orientation scores while also learning best practices from other nations, such as Thailand, for benchmarking purposes.

Leadership Orientations. Leadership is a science as it can be studied over time by understanding the leaders, the followers, and the situational conditions along with the interactions taking place between the leaders and situational or cultural conditions (Habil, Aboramadan, and Zaqout, 2019; Barnard, 1948; Bass, 1990). In the leadership literature, the behaviors of leaders are discussed in terms of initiating structure (task-orientation) and consideration (relationship-orientation) components (Halpin and Winer, 1957; Fleishman, 1967). Bass (1990) found that relationship-oriented functions are associated with subordinate satisfaction, and taskoriented functions are linked with performance. Similarly, the relationship functions are positively associated with a group performance, which explains why Afghans and Thais work well in teams. Overall, situational leadership theory states that the best leadership style depends on the variables surrounding each decision, person, and strategy. One dimension of each person's leadership style is the extent to which he or she is peopleoriented or task-oriented. Since cultures influence people through years of socialization, this study aids in determining and confirming whether people of high-context culture are more relationship-oriented or more task-oriented. 
Maintaining healthy relationships in a group is a top priority in Thailand and Afghanistan; consequently, leaders tend to avoid stressful disagreements and effectively manage dysfunctional conflicts in their organizations as quickly as possible (Nakane, 1970). The leader and followers in most Asian cultures exchange their opinions informally until a common understanding occurs to avoid conflicts in department and group meetings (Xu, 1987). After negotiating and reaching a consensus, which can be time-consuming, formal decisions are made. Generally, the Thai manager will not unilaterally decide until followers who will be affected, have had sufficient time to offer their views, feel they have been fairly heard, and are willing to support the agreed-upon decision even though they may feel that it is not the best one (Ouchi, 1976: 308). However, this is not always the case for managers in Afghanistan, as they tend to be more directive and authoritarian. To sum up Afghan and Thai leadership behaviors, the role of leaders in these Asian cultures is to maintain relationships, using autocratic, directive, authoritarian, democratic, and participative leadership approaches.

\section{Methodology}

Literature demonstrated that leaders and managers worldwide tend to use various amounts of task and relationship behaviors to motivate their followers and achieve organizational objectives. To get a better understanding of a leader or manager's style, Northouse (2007) provides the Style Questionnaire. This survey can be used to obtain a general profile of a person's leadership behaviors regarding task and relationship orientations. Like previous studies by the authors, this instrument was selected because it has short statements that make it easy for the respondents to fill them out. In a cross-cultural environment, it leaves little room for misunderstandings and misinterpretations. The statistical output for the reliability data has shown that the Cronbach's alpha is 0.887 , which means that the questions are good for tests, and they are acceptable in social science research (Nguyen, Mujtaba, Tran, and Rujis, 2013; Nguyen, Mujtaba, \& Pham, 2013). Overall, in the Style Questionnaire, each respondent must circle one of the options that best describe him or her regarding each statement that relates to getting the job done or keeping the relationship strong. In other words, for each statement, the respondent indicates the degree to which he or she (or the person being evaluated) engages in the stated behavior. In the Style Questionnaire, a rating of 1 means "never," and a rating of 5 means "always," with the person demonstrating the specific behavior. To determine one's scores for the leadership styles questionnaire, researchers add the responses for the odd-numbered items to determine the score for taskorientation behaviors and add the responses for the even-numbered items to determine the score for relationship-orientation behaviors. Northouse's (Northouse, 2007: 87) scoring interpretation ranges from "Very high" to "Very low," as shown in Table 1.

Table 1. Task and Relationship Score Interpretations

\begin{tabular}{|c|c|}
\hline Score range & Description \\
\hline $45-50$ & Very high range \\
\hline $40-44$ & High range \\
\hline $35-39$ & Moderately high range \\
\hline $30-34$ & Moderately low range \\
\hline $25-29$ & Low range \\
\hline $10-24$ & Very low range \\
\hline
\end{tabular}

Source: Northouse, 2007 , p. 87

Sampling Procedures. This study targeted Afghan and Thai citizens, workers, and managers. The original questionnaire was translated into the Thai and Persian languages to increase both accuracy and response rate so that those who were not fluent in English could quickly respond to each question. The Thai and Persian versions of the survey were back-translated into English by two other individuals to confirm their accuracy with the original instrument. The printed surveys were offered in Thailand and Afghanistan to individuals who volunteered to complete them. The online version of the survey was only available in English. The surveys were distributed and collected physically and sent electronically to working adults, graduate students, colleagues, and friends who live worldwide. The self-administered questionnaire offers anonymity (Nguyen, Mujtaba, \& Pham, 2013), which is essential when conducting research related to the leadership and management characteristics of respondents or their superiors. For purpose of this study, 400 candidates' responses were selected for analysis from each nation, with a response rate of 30\% in Afghanistan and 65\% in Thailand. The convenience sample was obtained through educational organizations, businesses, entrepreneurs, and private and public sector institutions. A paragraph explaining the purpose of this research and guaranteeing confidentiality were included with the survey. The respondents were asked to complete the questionnaire, using print or online format voluntarily. 


\section{Research Hypotheses}

The research question for this study was to determine whether Afghan and Thai respondents have similar or different scores on the relationship orientation and task orientation dimensions of leadership. The specific hypotheses for this study are as follows:

Hypothesis 1: Thai respondents will have similar scores for relationship and task orientations.

Hypothesis 2: Afghan and Thai respondents will have similar scores on task and relationship orientation.

\section{Task and Relationship Orientation Results}

Like our previous studies, the current data analysis demonstrates that Afghans are highly task-oriented and relationship-oriented. Yes, Afghan respondents have been shown to have statistically significant differences in their task and relationship orientations. Afghan respondents have dissimilar scores for relationship and task orientations as they are more highly focused on their relationships. Let us see how different the task and relationship orientations of Afghans from their Thai colleagues are. Thai respondents also appear to have high scores in both their task and relationship orientations. While the average score of Thai respondents for task and relationship orientations falls in "high range," there are statistically significant differences among them.

Table 2. Thai Task vs. Relationship Orientations

\begin{tabular}{|c|c|}
\hline Level of Significance & 0.05 \\
\hline \multicolumn{2}{|c|}{ Task Orientation } \\
\hline Sample Size & 400 \\
\hline Sample Mean & 41.51 \\
\hline Sample Standard Deviation & 2.86 \\
\hline \multicolumn{2}{|c|}{ Relationship Orientation } \\
\hline Sample Size & 400 \\
\hline Sample Mean & 43.36 \\
\hline Sample Standard Deviation & 2.324 \\
\hline \multicolumn{2}{|c|}{ Intermediate Calculations } \\
\hline Total Degrees of Freedom & 798 \\
\hline Pooled Variance & 6.790288 \\
\hline Difference in Sample Means & -1.85 \\
\hline$t$-Test Statistic & -10.04 \\
\hline \multicolumn{2}{|c|}{ Two-Tailed Test } \\
\hline Lower Critical Value & -1.963 \\
\hline Upper Critical Value & 1.963 \\
\hline$p$-Value & 0.00 \\
\hline
\end{tabular}

Source: Compiled by the authors

As can be seen from Table 2 and using the t-test for differences in two means, at a 0.05 level of significance, the first hypothesis is rejected because the calculated t value (-10.04) does not fall within the critical value of $\mathrm{t}$ for statistical significance; thus, the alternative hypothesis is supported. Furthermore, since the $\mathrm{p}$-value of 0.00 is smaller than alpha $(\alpha)=0.05$, there is sufficient evidence to reject the hypothesis. Therefore, Thai respondents have dissimilar scores for relationship and task orientations as they are more highly focused on their relationships which is similar to the results demonstrated by the Afghan respondents (Mujtaba, 2019b). Based on the results, the task orientation and relationship orientation scores of Thai respondents do not appear to be similar. As such, one can conclude that Thai employees and managers have significantly higher scores on the relationship orientation. Perhaps because of their high context and collective nature, Thai respondents are putting significantly more emphasis on their relationships. These results are similar to those of the Afghan respondents; it means that both Thai and Afghan respondents demonstrate a significantly higher focus on their relationships, as compared to their task-orientation.

As can be seen from Tables 3 and 4, the second hypothesis cannot be rejected because the calculated t value (1.08) for task orientation of Afghans and Thais does fall within the critical values of t (-1.963 - 1.963) for statistical significance. Also, since the p-value of 0.279 is larger than alpha $(\alpha)=0.05$, there is sufficient evidence to support the hypothesis. Furthermore, as can be seen in Table 4, analysis on the relationship orientation of Afghan and Thai respondents demonstrated that the calculated $t$ value (-1.47) falls within the critical value of $\mathrm{t}$ for statistical significance; in other words, the hypothesis is supported. Furthermore, since the p-value of 0.141 is greater than alpha $(\alpha)=0.05$, there is sufficient evidence to support the hypothesis. Therefore, Afghan and Thai respondents have similar scores for task and relationship orientations. 
Table 3. Thai and Afghan Task Orientations

\begin{tabular}{|c|c|}
\hline Level of Significance & 0.05 \\
\hline \multicolumn{2}{|c|}{ Thai Task Orientation } \\
\hline Sample Size & 400 \\
\hline Sample Mean & 41.51 \\
\hline Sample Standard Deviation & 2.86 \\
\hline \multicolumn{2}{|c|}{ Afghan Task Orientation } \\
\hline Sample Size & 400 \\
\hline Sample Mean & 41.0825 \\
\hline Sample Standard Deviation & 7.353 \\
\hline \multicolumn{2}{|c|}{ Intermediate Calculations } \\
\hline Total Degrees of Freedom & 798 \\
\hline$t$-Test Statistic & 1.08 \\
\hline \multicolumn{2}{|c|}{ Two-Tailed Test } \\
\hline Lower Critical Value & -1.963 \\
\hline Upper Critical Value & 1.963 \\
\hline$p$-Value & 0.279 \\
\hline
\end{tabular}

Source: Compiled by the authors

Table 4. Thai and Afghan Relationship Orientations

\begin{tabular}{|c|c|}
\hline Level of Significance & 0.05 \\
\hline \multicolumn{2}{|c|}{ Afghan Relationship Orientation } \\
\hline Sample Size & 400 \\
\hline Sample Mean & 43.87 \\
\hline Sample Standard Deviation & 6.523 \\
\hline \multicolumn{2}{|c|}{ Thai Relationship Orientation } \\
\hline Sample Size & 400 \\
\hline Sample Mean & 43.36 \\
\hline Sample Standard Deviation & 2.324 \\
\hline \multicolumn{2}{|c|}{ Intermediate Calculations } \\
\hline Total Degrees of Freedom & 798 \\
\hline Pooled Variance & 23.9752525 \\
\hline Difference in Sample Means & -0.51 \\
\hline$t$-Test Statistic & -1.47 \\
\hline \multicolumn{2}{|c|}{ Two-Tailed Test } \\
\hline Lower Critical Value & -1.963 \\
\hline Upper Critical Value & 1.963 \\
\hline$p$-Value & 0.141 \\
\hline
\end{tabular}

Source: Compiled by the authors

\section{Discussion}

Due to people's collective cultures with the country's economic success, one could assume that Thai respondents would have similar scores for relationship and task orientations. However, our research did not support this hypothesis because Thais are more focused on their leadership element; this shows the same trend for Afghan respondents. This study's result supports previous literature on the Thai and Afghan cultures, organizations, and management practices that they lead and manage by maintaining harmony in their relationships as "face-saving" is so essential for harmony in these Asian cultures. Thais and Afghans are more relationship-oriented than task-oriented; however, their task orientation falls in the high range as well. Global managers should pay attention to the reality that Afghan and Thai management practices are based on their relationship orientation and getting along with all relevant stakeholders through effective teamwork, participative decision-making, and cooperation.

Overall, the findings of this research are consistent with previous studies conducted with Thai working adults (Sungkhawan, Mujtaba, Swaidan, and Kaweevisultrakul, 2012; Murphy Jr., Mujtaba, Manyak, Sungkhawan, and Greenwood, 2010; Mujtaba, Luk, Murphy, and Saowakul, 2009), and Afghan respondents. Learning and benchmarking leadership best practices can take place in any country or culture. The hope for every leader is that we make a positive difference in the lives of those around us between birth and death. Afghans should learn from their own positive and negative trends in the past and the positive and negative patterns of other cultures and countries. As the proverb goes, those who do not know history are likely to repeat it. As such, we should learn from the past to positively influence our lives in the present and future.

The political leaders of Thailand have been able to use their high relationship orientation positively with the international community by keeping a strong bond with their neighbors and other nations both in the west and 
east. Consequently, the people of Thailand have enjoyed a better quality of life through a sustaining peaceful work environment, inclusion, democracy, and a stronger and progressively developing economy (Senathip, Mujtaba, and Cavico, 2017). In today's Covid-19 world, where the coronavirus and pandemic has dramatically increased unemployment rates and decreased economic activities, political leaders in Thailand seem have done a fairly good job of managing the task of reducing the spread of the virus and its resulting deaths by promptly implementing relevant actions and policies. Sadly, it has not been the case in efficiently dealing with the task of stopping the spread of the coronavirus in Afghanistan due to the political conflicts among different groups and the poor state of the Afghan economy, which has been largely dependent on the international community.

We know that effective leadership is even more important during crisis events and pandemics. For example, even though the United States' economy was powerful before the Covid-19 pandemic, due to a lack of an effective national strategy and timely response, the country has had about 600,000 deaths as of July 2021 . The United States was expected to be able to not only effectively manage this pandemic crisis well for their people as this rich nation has some of the best laboratories and diverse medical experts from around the world, but they were also expected to help other nations. Yet, due to a lack of adequate and trustworthy political leadership, nearly 35 million Americans lost their jobs in 2020, with diverse minorities and women suffering the most, and the U.S. economy experienced its worst depression for almost a century now. Even though Americans are expected to be high in their task orientation due to their individualist culture and socialization, influential and trustworthy leadership was needed during 2020 to focus diverse people groups toward a clear vision and mission. Of course, the new administration during early 2021 brought about much-needed political leadership and stability in effectively managing the vaccination process for the Covid-19 coronavirus in the United States of America. While Thailand has people of diverse ethnic backgrounds, they seem to be more inclusive and effective at synergizing because of their differences.

Thais have less blatant forms of ethnic animosity, conflict, gender discrimination, and workplace mobbing of those who are different from everyone else. Perhaps Afghan leaders should take advantage of their relationship orientation element of leadership to build strong bonds and connections within the country's diverse tribal groups, as well as with their neighbors and other influential nations around the globe. Author Jordan Raynor (2020) states that most individuals spend their days, weeks, and years making little progress in a million different directions; thus, they become competent at many things but exceptional at none of them. Raynor (2020) recommends that modern leaders explore, choose, eliminate, and master the "one thing" that will make a long-lasting, impactful, and sustainable positive difference in their lives. It is exactly what the father of scientific management, Frederick Taylor, emphasized at the beginning of the 20th century when he said managers and leaders should find employees who are "First-Class" at doing each specific task. Taylor believed that everyone is a "first-class" worker, and managers should match employees with the right jobs. Afghan leaders should focus on their strong points while also studying the Thai culture of politics and business practices to implement the relevant ones in Afghanistan. One critical area for immediate improvements in Afghanistan is to offer more opportunities for females to get quality education at all levels while also battling the devious societal mobbing (group bullying of those who are different) practices based on ethnic, religious, and/or political differences. In any culture, influential leaders are ultimately responsible for establishing ethical strategies that the country should implement in the present to create a better and ideal future. It is imperative in Afghanistan that leaders become ethical role models and deliver what they promise to others in the community, country, region, and society by reducing and eradicating mismanagement. It is the responsibility of all public officials and private sector leaders to be culturally competent, ethical role models. It is a fact that specific training and educational programs can significantly enhance human development and critical thinking. Educated critical thinkers should be trained to be open-minded and self-directed as they discipline and monitor their views before implementing a significant decision.

Critical thinkers purposely and explicitly go beyond their intuition or gut feelings to analyze and assess all the facts in a given situation to be consistently fair to all stakeholders in a decision. Critical thinkers live fairmindedly while internalizing and promoting universal values. Like all studies, there are some limitations to this study. First, the small number of responses from a convenient population is one of them. Future studies should compare specific populations in different parts of each country with similar working backgrounds and demographic variables. Afghan and Thai populations seem to have a significantly higher focus on relationship orientation. It might be true simply because they understand the importance of maintaining good relations with others due to the economic necessities and not necessarily years of cultural socialization. Researchers should also note that the quality of education might also be an important variable or factor in respondents' scores. Therefore, future studies should test "sub-cultures," "gender," and "education" to see if these are significant variables in the task and relationship orientation scores of respondents in each culture. 


\section{Implications for Practice}

Afghanistan's population will soon be going beyond 40 million people, and their current literacy rate is still about 30 percent. Since their population is growing rapidly, leaders must focus on the education of all diverse Afghans, especially the young and upcoming leaders, to help them become globally competent. Sadly, about 70 percent of Afghans have no formal schooling experience due to the poor economy, lack of proper security, and several decades of war. The starting point for progress can be strengthening the government branches in Afghanistan so all managers and representatives can be effective role models of cultural inclusion, continuous learning, and education to enforce high ethical standards (Cavico and Mujtaba, 2018; De Maria, 2008). For centuries, an overlooked and under-represented group in Afghanistan has been the female population. The agony for Afghanistan's women must come to an end if the country benefits from the talent of its entire population from all minority groups (Haidari, 2010). Luckily, according to Haidari (2010), the Afghan Parliament continues to convene with a higher percentage of female representatives $(27.3 \%)$ than the legislative bodies of most established democracies, including the U.S. Congress (15.2\%) and British Parliament (19.7\%). Despite some progressive advances, sadly, one woman dies every 29 minutes in childbirth in Afghanistan.

Furthermore, only $12 \%$ of females 15 years and older can read and write at the basic levels, compared to $39 \%$ of men in Afghanistan. The overall literacy rate for women between the ages of 15 and 24 stands at 24\%, compared to 53\% for men in Afghanistan. Haidari emphasizes that this troubling situation is a legacy of decades of war and state collapse. Unfortunately, with a weak government and lack of appropriate infrastructure developments in the country, such statistics will continue to be realities in Afghanistan for the next few decades to come. Afghans have a long way to go before providing a fair, just, and secure environment for everyone in Afghanistan. The Afghan government officials must continue to create, lead, and implement culturally inclusive and sustainable policies (Wolf and Mujtaba, 2011), simultaneously functioning as agents of social change to ameliorate the traditional views that prevent the female and other minority populations in Afghanistan from becoming full contributors in the development process. For women and all diverse Afghans to be fully empowered to make a significant contribution to Afghanistan's long-term development, the international community must continue to help the Afghan government become stronger and more focused on cultural inclusion, as well as the leadership training and equal treatment of all individuals in the country (Cavico and Mujtaba, 2018).

Societal Mobbing and Inclusion Training. Training and development of everyone in the Afghan society should be strategic to socialize them to become more inclusive, like the Thai culture where diverse groups work together toward common goals. For example, in most places in Thailand, men and women of various backgrounds can cohesively live and work together without anyone being blatantly discriminated based on their different genders, ethnicities, religious beliefs, or appearances. Afghans need to be educated, trained and developed to adopt similar inclusive mindsets in the context of their own culture and religious beliefs. Sadly, stereotypical views and prejudices based on gender and ethnicity have been widespread in Afghanistan for decades. However, some politicians, warlords, and gangs seem to have used existing prejudices for sinister purposes all the way to terrorizing people simply because they are different from the majority. We call this concept "societal mobbing," where an innocent victim is regularly bullied by members of the community, by gangs, and through like-minded colleagues in the workplace. Such negative practices can lead to high employee turnover and layoffs as the best employees would leave, thereby hurting the organization's profitability and sustainability (Mujtaba and Senathip, 2020a).

For example, Afghan minorities of all ethnic backgrounds (Hazaras, Hindus, Uzbeks, etc.) have been physically hurt, ostracized, abused, and often consistently harassed with stereotypical jokes in the workplace. Similarly, qualified females are not afforded opportunities and privileges that are available to most men. The popular book and movie entitled "The Kite Runner" by Khalid Hossieni provide some examples of how prejudices, biases, and stereotypical norms in the Afghan culture can lead to societal mobbing. While development focuses on the audience's educational needs, training is the process of teaching everyone the basic skills they need to immediately function as productive members of the department, community, and society at large. Training has an impressive record of influencing organizational effectiveness and its effect on productivity tends to be higher than performance appraisal and feedback and just below goal setting (Noe, Hollenbeck, Gerhart, and Wright, 2019). As such, it should have similar outcomes when it is targeted toward the needs of communities and society as well. One area where Afghans need training is diversity and inclusion so people can avoid stereotypes and bullying (mobbing) of women and minority members in the community and workplace. While diversity is about having members of all ethnic backgrounds from the community being 
represented in the workplace, inclusion relates to making sure that they are all equally engaged in the significant decisions of the organization and society. Diversity is about being invited to an event or party, while inclusion is having an active part in it as per one's area of responsibility and competence without being isolated, bullied, or harassed due to one's gender, ethnicity, religion, disability, or appearance.

Societal mobbing can involve two or more like-minded individuals, friends, colleagues, and/or employees ganging up to target or consistently bully a person through isolation, humiliation, and aggression (Mujtaba and Senathip, 2020b). The victim is often selected because he or she has a unique view or is somewhat different from everyone else based on his/her gender, ethnicity, religion, body size, appearance, age, leadership style, rank, sexual orientation, etc. Compared to individually bullying another person, societal mobbing involves a group of individuals against a specific target who is different from everyone else regarding his/her views, thoughts, and/or some dimension of diversity. If there is no effective intervention for the workplace or societal mobbing, it can lead to continued conflicts, suicides and/or the voluntary or involuntary turnover and brain drain of qualified employees into foreign nations.

Extreme forms of peer pressure, bullying, mobbing, and systematic soldiering can cause much unnecessary conflict in the workplace, especially in diverse departments and organizations (Baillien, Camps, Van den Broeck, Stouten, Godderis, Sercu \& De Witte, 2016; De Cieri, Sheehan, Donohue, Shea, \& Cooper, 2019; Wall, Smith, \& Nodoushani, 2018). While workplace mobbing can be very stressful for the victim and other professionals, managers, and observers alike, some best practices and procedures must be followed to make the workplace fair and just for all parties involved. It is mainly in the worker's mind that believes he/she is a victim of workplace mobbing. Managers and all professionals must always behave rationally and professionally by objectively following relevant policies and guidelines to ensure the workplace is a good environment for everyone. Managers and politicians must create appropriate training programs and policies to effectively deal with such challenges to create an inclusive workplace and society for all diverse Afghans. Training and development practices are essential for a healthy society, department, and organizational culture (Quinn, Spreitzer \& Lam, 2012; Ray, 1986; Ouchi, 1979). It should be noted that the cultural control and the leadership role of change agents, as connectors or transitional agents, play a critical role in investigating, communicating, and regularly assessing managers and employees so they can internalize the organization's desired values and expected norms (Merchant and Van der Stede, 2007; Malmi and Brown, 2008). Afghan managers and politicians need to become transitional connectors and change agents who can help people move toward peace and progress in the economy by demonstrating patience and cultural inclusion at all levels of the society.

\section{Conclusion}

This research provided a cursory overview of the culture and people of Afghanistan and Thailand. The paper also discussed the Afghan culture's norm of getting along, which influences their relationship orientation. Most Afghans have an attitude of cooperating, getting along, showing restraint, win-win thinking, avoiding unnecessary risks, being sustainable, and doing whatever is necessary to preserve meaningful relationships and "save face." While the Thais may live far from Afghanistan and speak a different language, their culture and daily behaviors seem mostly aligned with this concept of "getting along" since it implies that one's actions should always cooperate, team-oriented, "saving face", and being sustainable. Today's global and competitive work environment, especially in developing economies such as Afghanistan, needs educated and strong leaders and change agents who think critically about their decisions based on current facts and developmental needs. Since both countries have similar cultural orientations, Afghan leaders and managers can better educate themselves by learning many of the relevant best practices, such as the inclusion of all diversities, making Thailand successful and applying them to their own country in Afghanistan. Overall, this study explored the basics of Afghan and Thai leadership orientations based on quantitative research and provided information for local and global managers about the mechanism of their behavior by more closely exploring the culture of Afghanistan. Recommendations for discussion, reflection, and training related to inclusion and workplace mobbing are presented.

Author Contributions: Conceptualization: Bahaudin G. Mujtaba, Tipakorn Senathip, Jatuporn Sungkhawan; data curation: Bahaudin G. Mujtaba, Tipakorn Senathip, Jatuporn Sungkhawan; formal analysis: Bahaudin G. Mujtaba, Tipakorn Senathip, Jatuporn Sungkhawan; investigation: Bahaudin G. Mujtaba, Tipakorn Senathip, Jatuporn Sungkhawan; methodology: Bahaudin G. Mujtaba, Tipakorn Senathip, Jatuporn Sungkhawan; project administration: Bahaudin G. Mujtaba, Tipakorn Senathip, Jatuporn Sungkhawan; resources: Bahaudin G. Mujtaba, Tipakorn Senathip, Jatuporn Sungkhawan; software: Bahaudin G. Mujtaba, Tipakorn Senathip, Jatuporn Sungkhawan; supervision: Bahaudin G. Mujtaba, Tipakorn Senathip, Jatuporn 
Sungkhawan; validation: Bahaudin G. Mujtaba, Tipakorn Senathip, Jatuporn Sungkhawan; visualization: Bahaudin G. Mujtaba, Tipakorn Senathip, Jatuporn Sungkhawan; writing - original draft: Bahaudin G. Mujtaba, Tipakorn Senathip, Jatuporn Sungkhawan; writing - review \& editing: Bahaudin G. Mujtaba, Tipakorn Senathip, Jatuporn Sungkhawan.

Funding. There is no funding for this research.

\section{References}

1. Adler, N.J. (1986). International Dimensions of Organizational Behavior. Kent Publishing: Boston, MA. [Google Scholar]

2. Ahmad, A., Hussain, A., Saleem, M.Q., \& Qureshi, M.A.M. (2015). Workplace Stress: A Critical Insight of Causes, Effects and Interventions. Technical Journal, University of Engineering and Technology (UET) Taxila, Pakistan, 20(II), 46-48. Available at: [Link]

3. Ahmed, S.K., Khan, M.M., Khan, R.A., \& Mujtaba, B.G. (March 2020). The Relationship between Social Capital and Psychological Well-Being: The Mediating Role of Internet Marketing. Marketing and Management of Innovations, 1, 40-53. [CrossRef]

4. Al-Kwifi, O.S., Khoa, T.T., Ongsakul, V. \& Ahmed, Z.U. (2020). Determinants of female entrepreneurship success across Saudi Arabia. Journal of Transnational Management, 25(1), 3-29. [Google Scholar] [CrossRef]

5. Ali, A.J. \& Al-Aali, A. (2016). Human capital and crisis management. Journal of Transnational Management, 21(4), 200-216. [Google Scholar]

6. Arslan, A., \& Dikova, D. (2015). Influences of Institutional Distance and MNEs' Host Country Experience on the Ownership Strategy in Cross-Border M\&As in Emerging Economies. Journal of Transnational Management, 20(4), 231-256. [Google Scholar] [CrossRef]

7. Baha, B. (2019). The Progress of Higher Education in Afghanistan. SAE eNewsletter, 9(4), 3-17. Available at: [Link]

8. Baillien, E., Camps, J., Van den Broeck, A., Stouten, J., Godderis, L., Sercu, M., \& De Witte, H. (2016). An eye for an eye will make the whole world blind: Conflict escalation into workplace bullying and the role of distributive conflict behavior. Journal of Business Ethics, 137(2), 415-429. [Google Scholar] [CrossRef]

9. Barnard, C.I. (1948). The nature of leadership, in Organization and Management: Selected Papers. Harvard University Press: Cambridge, MA. Available at: [Link].

10.Bass, B.M. (1990). Bass and Stogdill's Handbook of Leadership: Theory, Research, and Managerial Applications, $3^{\text {rd }}$ ed. Free Press: New York, NY. [Google Scholar]

11.Bass, B.M. and Bass, R. (2008). The Bass Handbook of Leadership: Theory, Research, and Managerial Applications. Free Press: New York, NY. Available at: [Link]

12.Buckner, E. (June 2019). The Internationalization of Higher Education: National Interpretations of a Global Model. Comparative Education Review, 63(3), 315-336. [Google Scholar] [CrossRef]

13.Cavico, F.J., and Mujtaba, B.G. (2018). Teaching Law, Ethics, and Social Responsibility in a School of Business: A Value-Driven Approach to Leadership and Sustainability. Marketing and Management of Innovations, 4, 263-281. [Google Scholar] [CrossRef]

14.Cavico, F.J., and Mujtaba, B.G. (2011). Baksheesh or Bribe: Cultural Conventions and Legal Pitfalls. ILEAD Academy Publications; Florida. Available at: [Link]

15.Dastoor, B., Roofe, E., and Mujtaba, B. (2005). Value Orientation of Jamaicans Compared to Students in the United States of America. International Business and Economics Research Journal, 4(3), 43-52. [Google Scholar] [CrossRef]

16.De Cieri, H., Sheehan, C., Donohue, R., Shea, T., \& Cooper, B. (2019). Workplace bullying: an examination of power and perpetrators. Personnel Review, 48(2), 324-341. [Google Scholar] [CrossRef]

17.Drumm, M. H. (2002). The ethical and moral development difference of municipal department heads based on the Defining Issues Test (Publication № AAT 3069473) Pro-Quest Digital Dissertations. Available at: [Link]

18.Duffy, M. \& Sperry, L. (2012). Mobbing: Causes, Consequences and Solutions. Oxford University Press Inc. [Google Scholar]

19.Entezar, Ehsan (2008). Afghanistan 101: Understanding Afghan Culture. Xlibris Corporation: United States. Available at: [Link]

20.Fleishman, E.A. (1967). Development of a behavior taxonomy for describing human tasks: a correlationalexperimental approach. Journal of Applied Psychology, 51(1), 1-10. [Google Scholar] [CrossRef]

21.Gardenswartz, L., Rowe, A., Digh, P., \& Bennett, M.F. (2003). The global diversity desk reference: Managing an international workforce. San Francisco, CA: Pfeiffer. 512 p. Available at: [Link] 
22.Gerhart, B. (2008). Cross cultural management research: Assumptions, evidence, and suggested directions. International Journal of Cross-Cultural Management, 8(3), 259-274. [Google Scholar] [CrossRef]

23. Ghoshal, S. (2005). Bad management theories are destroying good management practices. Academy of Management Learning and Education, 4(1), 75-91. [Google Scholar] [CrossRef]

24.Habil, W., Aboramadan, E.M., and Zaqout, E. (2019). Leadership competencies of middle managers and employees' job performance: evidence from a Palestinian media channel. Middle East Journal of Management, 6, 671. [Google Scholar] [CrossRef]

25.Haghirian, P. (2010). Understanding Japanese Management Practices. Business Expert Press: New York, NY. 174 p. Available at: [Link]

26.Haidari, A.M. (March 9, 2010). A new chance for women (in Afghanistan). The Washington Times. Available at: [Link]

27.Hall, E.T. (1976). Beyond Culture. Anchor Books: New York, NY. 315 p. Available at: [Link]

28.Halpin, A.W., and Winter, B.J. (1957). A factorial study of the leader behavior descriptions Bureau of Business Research. Ohio State University, Research Monograph, 88, 30-51. Available at: [Link]

29.Harzing, A. (2006). Response styles in cross-national survey research: A 26-country study. International Journal of Cross Cultural Management, 6(2), 243-266. [Google Scholar] [CrossRef]

30.Hersey, P. (2008). Personal Communication on Situational Leadership. One-week Train-the-Trainer Workshop by Dr. Hersey and facilitators of The Center for Leadership Studies, February 2008, Escondido, CA. Available at: [Link]

31.Hersey, P. (1984 \& 1997). The Situational Leader. The Center for Leadership Studies Escondido, CA. [Google Scholar]

32.Hersey, P., Blanchard, K., and Johnson, D. (2001). Management of Organizational Behavior. Eighth edition. Prentice Hall. Available at: [Link]

33.Hofstede, G. (2001). Culture's consequences: Comparing values, behaviors, institutions, and organizations across nations ( $2^{\text {nd }}$ ed.). Thousand Oaks, CA: Sage. [Google Scholar]

34.Hofstede, G. (1991). Culture and Organizations: Software of the Mind. McGraw-Hill: New York, NY. [Google Scholar]

35.Hofstede, G. (1989). Cultural Predictors of National Negotiation Styles, in F. Mautner-Markhof, ed., Processes of International Negotiations, 193-201. [Google Scholar]

36.Hofstede, G. (1980). Culture's Consequences: International Differences in Work-Related Values. Sage: Beverly Hills, CA. [Google Scholar]

37.Huang, J.L., Ryan, A.M., and Mujtaba, B.G. (2015). Vicarious experience of justice: when unfair treatment of one's colleague matters. Personnel Review, 44(6), 826-846. [Google Scholar] [CrossRef]

38.Huang, C., Mujtaba, G.B., Cavico, F., and Sims, R.L. (2006). Ethics and Executives: A Cross-Cultural Comparison of Japan, Taiwan, and the United States. International Business and Economics Research Journal, 5(7), 9-22. [Google Scholar] [CrossRef]

39.Hughes, R.L., Ginnett, R.C., and Curphy, G.J. (2019). Leadership: Enhancing the Lessons of Experience, ninth edition. McGraw Hill: New York. Available at: [Link]

40.Ibrahim, A.R., Imtiaz, G., Mujtaba, B.G., Vo, X.V. \& Ahmed, Z.U. (2020). Operational Excellence through Lean Manufacturing: Considerations for Productivity Management in Malaysia's Construction Industry. Journal of Transnational Management, 25(3), 225-256. [Google Scholar] [CrossRef]

41.Jogulu, U.D. (2010). Culturally-linked leadership styles. Leadership \& Organization Development Journal, 31(8), 705-19. [Google Scholar] [CrossRef]

42.Kaifi, B., Mujtaba, B.G., and Xie, Y. (2009). The Perception of Afghan-American Leaders' Role in Economic Development Efforts in Afghanistan: A Study of Gender Differences and Repatriation to the Motherland. Journal of Diversity Management, 4(3), 35-46. [Google Scholar] [CrossRef]

43.Karadjova-Stoev, G., and Mujtaba, B.G. (2009). Strategic Human Resource Management and Global Expansion Lessons from the Euro Disney Challenges in France. International Business and Economics Research Journal, 8(1), 69-78. [Google Scholar] [CrossRef]

44.Karahalios, M., and Mujtaba, G.B. (2006). Women, Disabilities, Technology, and the Reconstruction of Afghanistan. Society of Afghan Engineers Journal, 3(1), 38-47. [Google Scholar]

45.Kashima, E.S., \& Hardie, E.A. (2000). The development and validation of the relational, individual, and collective self-aspects (RIC) scale. Asian Journal of Social Psychology, 3(1), 19-48. [Google Scholar] [CrossRef]

46. Korman, K., and Mujtaba, B.G. (2020). Corporate Responses to COVID-19 Layoffs in North America and the Role of Human Resources Departments. Reports on Global Health Research, 3(2), 1-17. [Google Scholar]

47.Kouzes, J., \& Posner, B. (2003). Encouraging the heart. San Francisco, CA: Jossey-Bass. [Google Scholar] 48.Kreitner, R. (2007). Management (10 ${ }^{\text {th }}$ ed.). Boston, MA: Houghton Mifflin. Available at: [Link] 49.Lawrence-Lightfoot, S. (2000). Respect. Cambridge, MA: Perseus Books. Available at: [Link] 
50.Lee, J.W. and Suwimol, N. (2018). Relationships between development policy, SMEs and total factor productivity in Thailand. Journal of Transnational Management, 23(4), 138-153. [Google Scholar] [CrossRef]

51.Malmi, T., \& Brown, D.A. (2008). Management control systems as a package - Opportunities, challenges and research directions. Management Accounting Research, 19(4), 287-300. [Google Scholar] [CrossRef]

52.McFarlane, D.A., Mujtaba, B.G., and Cavico, F.J. (2009). The Business School in the $2^{\text {st }}$ Century and Beyond: Integrating Knowledge Management Philosophy. Journal of Knowledge Management Practice, 10(4), 1-11. [Google Scholar]

53.Merchant, K.A., \& Van der Stede, W.A. (2007). Management control systems: performance measurement, evaluation and incentives. Harlow, UK: Pearson Education. [Google Scholar]

54.Minzberg, H. (1985). The organization as political arena. Journal of Management Studies, 22, 133-154. [Google Scholar] [CrossRef]

55.Misumi, J., and Seki, F. (1971). Effects of achievement motivation on the effectiveness of leadership patterns. Administrative Science Quarterly, 16(1), 51-59. [Google Scholar] [CrossRef]

56.Misumi, J. (1986). The Behavioral Science of Leadership: An Interdisciplinary Japanese Research Program. University of Michigan Press: Ann Arbor, MI. [Google Scholar]

57.Molz, J. and Mujtaba, B.G. (2011). Toyota's Strides for Quality and Continuous Improvement: Japanese Pioneers in Value Creation and Lean Management. Proficient: An International Journal of Management, 3(5), 7-19. Available at: [Link]

58.Mujtaba, B.G. (2019a). Task and Relationship Orientation of Afghan and Thai Citizens: Training Recommendations for Effective Leadership. The $17^{\text {th }}$ International Conference on Language, Innovation, Culture, and Education 2019 Conference. Bangkok, Thailand. ICLICE Proceedings, 54-68. Available at: [Link]

59.Mujtaba, B.G. (2019b). Leadership Orientation of Afghan and Japanese Respondents: A Study of "Guzaara" or Getting Along in Asia. Information Management and Business Review, 11(1), 24-39. [Google Scholar]

60.Mujtaba, B.G., and Senathip, T. (2020a). Layoffs and Downsizing Implications for the Leadership Role of Human Resources. Journal of Service Science and Management, 13(2), 209-228. [Google Scholar] [CrossRef]

61.Mujtaba, B.G. and Senathip, T. (2020b). Workplace Mobbing and the Role of Human Resources Management. Business Ethics and Leadership, 4(1), 17-34. [Google Scholar]

62.Mujtaba, B.G., Cavico, F.J., and Senathip, T. (2020c). Strategies for Personal, Organizational and Professional Leadership Success. Scientific Journal of Research \& Reviews, 2(3), 1-10. Available at: [Link]

63.Munene, J.C., Schwartz, S.H., \& Smith, P.B. (2000). Development in sub-Saharan Africa: Cultural influences and managers' decision behavior. Public Administration and Development, 20(4), 339-351. [Google Scholar] [CrossRef]

64.Murphy Jr., E.F., Mujtaba, B.G., Manyak, T., Sungkhawan, J. and Greenwood, R. (2010). Generational Value Differences of Baby Boomers in Thailand. Asia Pacific Business Review, 16(4), 545-566. [Google Scholar] [CrossRef]

65.Nakane, C. (1974). Cultural anthropology in Japan. Annual Review of Anthropology, 3(1), 57-72. [CrossRef]

66.Nakane, C. (1970). Japanese Society. University of California Press: Berkeley, CA. [Google Scholar]

67.Nakane, C. (1967). Kinship and Economic Organizations in Rural Japan. Athlone Press: London. Available at: [Link]

68.Ng, P.K., \& Tung, B. (2018). The importance of reward and recognition system in the leadership of virtual project teams: a qualitative research for the financial services sector. Journal of Transnational Management, 23(4), 198-214. [Google Scholar] [CrossRef]

69.Nguyen, L.D., Mujtaba, B.G., Tran, C.N. and Rujis, A. (2013). Cross-culture management: an examination on task, relationship and work overload stress orientations of Dutch and Japanese working adults. International Journal of Strategic Change Management, 5(1), 41-58. Available at: [Link]

70.Nguyen, L.D., Mujtaba, B. G., \& Pham, L.N.T (2013). Cross culture management: An examination on task, relationship and stress orientations of Japanese and Vietnamese. International Journal of Strategic Change Management, 5(1), 72-92. [CrossRef]

71.Nieves, R., Mujtaba, B.G., Pellet, P., and Cavico, F.J. (2006). Culture and Universal Professional Values in Global Organizations: Is there a Divergence or Convergence of Cultural Values? Journal of Diversity Management, 1, 31-38. [Google scholar] [CrossRef]

72.Noe, R.A., Hollenbeck, J.R., Gerhart, B., and Wright, P.M. (2019). Human Resource Management: Gaining a Competitive Advantage (11 ${ }^{\text {th }}$ edition). McGraw-Hill: USA. Available at: [Link]

73.Northouse, P.G. (2007). Leadership: Theory and practice (4 ${ }^{\text {th }}$ ed.). Thousand Oaks, CA: SAGE. Available at: [Link]

74.Orbell, J., \& Dawes, R.M. (1991). A "Cognitive Miser" Theory of Cooperators Advantage. American Political Science Review, 85(02), 515-528. [Google Scholar] [CrossRef] 
75.Ouchi, W. (1979). A conceptual framework for the design of organization control mechanism. Management Science, 25(4), 833-848. [CrossRef]

76.Oyserman, D., Coon, H.M., \& Kemmelmeier, M. (2002). Rethinking individualism and collectivism: Evaluation of theoretical assumptions and meta-analysis. Psychological Bulletin, 128(1), 3-72. [Google Scholar] [CrossRef]

77.Petersen, Lainie (2019). What Is Mobbing at the Workplace? Chron.com. Available at: [Link]

78.Prahalad, C.K. (2010). The responsible manager. Harvard Business Review, 88(1), 36. Available at: [Link]

79.Quinn, R.W., Spreitzer, G.M., \& Lam, C.F. (2012). Building a sustainable model of human energy in organizations: Exploring the critical role of resources. The Academy of Management Annals, 6(1), 337-396. [Google Scholar] [CrossRef]

80.Ray, C.A. (1986). Corporate culture: The last frontier of control? Journal of Management Studies, 23(3), 287-297. [Google Scholar] [CrossRef]

81.Raynor, Jordan (2020). Master of One: Find and focus on the work you were created to do. Waterbrook: Canada. 218 p. [Google Scholar]

82.Reischl, J.N., Cavico, F.J., Mujtaba, B.G., and Pellet, P.F. (2010). The Quest for Logia Psyche in Business Leadership: An Empirical Study of Cognitive Moral Development in Construction Industry Dyads. Journal of Leadership Studies, 3(4), 6-22. [Google Scholar] [CrossRef]

83.Sanyal, R.E. (2005). Determinants of bribery in international business: the cultural and economic factors. Journal of Business Ethics, 59(1), 139-145. [Google Scholar] [CrossRef]

84.Scagliotti, G.V., and Mujtaba, B.G. (2010). Take a Bow: Culturally Preparing Expatriates for Doing Business in Japan. Journal of Comprehensive Research, 8(1), 71-87. Available at: [Link]

85.Scarborough, J. (1998). The origins of cultural differences and their impact on management. Westport, CN: Quorum Books. [Google Scholar]

86.Schwartz, S.H. (1999). Cultural value differences: Some implications for work. Applied Psychology, 48(1), 23-47. [CrossRef]

87.Schwartz, S.H. (1994). Beyond individualism/collectivism: New cultural dimensions of values. In U. Kim, H. C. Triandis, C. Kagitcibasi, S. C. Choi, G. Yoon (Eds), Individualism and Collectivism: Theory, Method and Applications (pp. 85-119). Newbury Park, CA: Sage. Available at: [Link]

88.Senathip, T., Mujtaba, B.G., and Cavico, F.J. (2017). Policy-Making Considerations for Ethical and Sustainable Economic Development. Economy, 4(1), 7-14. [Google Scholar]

89.Shallcross, L., Sheehan, M., \& Ramsay, S. (2008). Workplace mobbing: experiences in the public sector. International Journal of Organisational Behaviour, 13(2), 56-70. [Google Scholar]

90.Sims, R., and Mujtaba, B. (2005). The Influence of Human Development on National Corruption: Implications for Afghanistan. SAE/SAAE Conference Proceedings; Dec. 17-18, 2005; Kabul University; Kabul, Afghanistan. Available at: [Link]

91.Sungkhawan, J., Mujtaba, B.G., Swaidan, Z., and Kaweevisultrakul, T. (2012). Intrapreneurial Workplaces and Job Satisfaction: The Case of Thai Employees. Journal of Applied Business Research, 28(4), 527-542. [Google Scholar] [CrossRef]

92.Trompenaar, F. (1993). Riding the Waves of Culture: Understanding Diversity in Global Business. Irwin: New York, NY. Available at: [Link]

93.Tushman, M.E. (1977). A political approach to organization: A review and rational. Academy of Management Review, 2, 206-216. [Google Scholar] [CrossRef]

94.Wall, A.E., Smith, R.A., \& Nodoushani, O. (2018). Bullying in the workplace: The great balancing act of victim rights and organizational policies. Journal of Competitiveness Studies, 26(1/2), 107-123. [Google Scholar]

95.Wayne, S.J., \& Ferris, G.R. (1990). Influence tactics, affect, and exchange quality in supervisor subordinate interaction: A laboratory experience and field study. Journal of Applied Psychology, 75, 487-499. [Google Scholar] [CrossRef]

96.Wolf, F., \& Mujtaba, B.G. (2011). Sustainability in Service Operations. International Journal of Information Systems in the Service Sector (IJISSS), 3(1), 1-20. [CrossRef]

97. Yousef, D.A. (1998). Correlates of perceived leadership style in a culturally mixed environment. Leadership \& Organization Development Journal, 19(5), 275-284. [Google Scholar] [CrossRef]

98. Yuet-Ha, M. (1996). Orientating values with eastern way. People Management, 2(15), 28. Available at: [Link]

99.Zaqout, E., Habil, W., \& Aboramadan, M. (2019). Leadership competencies of middle managers and employees' job performance: evidence from a Palestinian media channel. Middle Eastern Journal of Management, 6(6), 671-694. [Google Scholar] [CrossRef] 